Shopping Streets versus Shopping Malls - Determinants of Agglomeration Format Attractiveness from the Consumers' Point of View

Christoph Teller

Institute for Retail Studies, University of Stirling

Stirling FK9 4LA, Scotland, UK

E-mail: christoph.teller@stir.ac.uk

TEL: +44 (0) 1786466454

FAX: +44 (0) 1786465290 


\section{Shopping Streets versus Shopping Malls - Determinants of Agglomeration Format Attractiveness from the Consumers' Point of View}

\section{ABSTRACT}

The decline of shopping streets and the rise of shopping malls have been major trends in European retailing for decades. So far, research has failed to investigate this shift of agglomeration format (AF) patronage from a marketing perspective, including the consumers' point of view. This paper presents a theoretical comparison of generic similarities and conceptual differences between shopping streets and shopping malls. Based on this comparison the AF-specific characteristics perceived by consumers are compared and discussed with respect to their impact on agglomeration attractiveness. This leads to the development of a conceptual framework which is empirically tested using a web-based survey of almost 1,000 consumers representing a typical urban central European retail market. The relative importance of nine distinctive AF characteristics on attractiveness was analysed using structural equation modelling. The findings proved to be quite similar for both shopping streets and shopping malls; the retail tenant mix and atmosphere had the highest relative importance.

Keywords: retail agglomeration, retail patronage, agglomeration format, shopping street, shopping mall

\section{INTRODUCTION}

Retailers seek out and locate next to other retailers in one place or in a nearby geographical area (Berman and Evans, 2007; Guy, 2007; Ingene, 1984). This spatial clustering or concentration tendency becomes manifest in 'retail agglomerations'. 
Several groups of store-based agglomeration types (thereafter named retail agglomeration formats (AF)) can be identified (Reimers and Clulow, 2004; Gilbert, 2003; Guy, 1995). Such a typology is based upon similarities of agglomerations with respect to how they are planned and constructed and consequently to what extent they are managed and marketed as integrated entities. This set of (typology) criteria has a strong impact on the retail mix of agglomerations (tenant mix, atmosphere, merchandise value, accessibility etc.). In other words, these criteria directly and indirectly influence the ability to adapt agglomeration characteristics to consumers' requirements and, thus, of being attractive for consumers and preferable over other competing AFs (Teller and Reutterer, 2008).

The most traditional AF group is denoted as evolved retail agglomeration formats (EAF), i.e. retail clusters in central business districts, inner-city locations or main streets (Levy and Weitz, 2006). The ownership of real estate is fragmented among a number companies or owners and the cooperation amongst retailers and other tenants to manage and market EAF is voluntary (Reimers and Clulow, 2004; Wrigley and Lowe, 2002; Guy, 1995;). In contrast, created retail agglomeration formats (CAF), i.e. (super)regional malls and other kinds of centres (strip, power, lifestyle, fashion/speciality, outlet or theme/festival centres (Levy and Weitz, 2006), are consciously planned and built and then managed and marketed centrally (Dennis, 2005). Beside these two format groups, retail parks denote a third hybrid format. These purpose-build clusters of free-standing stores on peripheral sites are developed consciously but are not marketed as a single site or unit (Gilbert, 2003).

This differentiated view of AF suggests certain structural and conceptual shortcomings of EAF compared to the other groups. These include the lack of low-cost floor space for large scale retailers, comparably poorer accessibility by car and parking facilities, traffic congestion, oversupply and/or shortage of certain retail formats, lack of shopping infrastructure (toilets, orientation guides) and promotional activities, varying opening hours of tenants, etc. (Gilbert, 2003; Levy and Weitz, 2006, Dennis, 2005, Reimers and Clulow, 
2004).

Many evolved agglomerations have lost attractiveness for consumers as shopping destinations and consequently for retailers as a location for their outlets. This has led to a shift of market share from EAF to particularly CAF in recent decades and the increase of the number and total floor space of gross leasable area and sales in CAF (CWHB, 2005; Guy, 1995; Whysall, 1995; Bearden, 1977; for a critical discussion see Jewell, 2001). This phenomenon affects in particular urban European retail markets where EAF have traditionally played a major role. There, most direct competition on a regional, and also super-regional, level has been taking place between the most typical and biggest representative of the two AF groups, i. e. between shopping streets (SST) and shopping malls (MAL). This is due to the fact that both $A F$ offer extensive and varied general merchandise and service and mostly appeal to the same urban customer groups (Levy and Weitz, 2006).

As a consequence, retail tenants but also tenants from the service and food sector of SST increasingly react by working together in order to enhance the attractiveness of their common location (Warnaby et al., 2004). They 'imitate' selected elements of the centre management and centre-marketing concept applied at MAL, in particular corporate promotional activities (Warnaby et al., 2002, 2004; Guy, 1995). Such initiatives may be an integrated part of a wider town/city centre management or place-marketing concept (Warnaby and Medway, 2004; Warnaby et al., 2002, 2003, 2004). Thus, in particular for SST, agglomeration marketing issues have become increasingly important and consequently the question of which marketing instruments to use in order to enhance their attractiveness compared to MAL or other CAF.

Two major streams in agglomeration format research can be distinguished: The first focuses on location planning and development of retail agglomerations. Here a considerable body of 
literature deals with the competition between EAF and CAF (see e.g. Thomas et al., 2006; Reimers and Clulow, 2004; Guy, 1995, 2007; Dennis et al., 2002; Wrigley and Lowe, 2002; Moreno-Jiménez, 2001; Whysall, 1995). In this work the terms planned and unplanned locations are frequently used for CAF and EAF. The second stream expands on retail agglomeration management and, in particular marketing issues (for a comprehensive overview see Teller and Reutterer (2008) or Dennis (2005)). This stream considers retail agglomerations as manageable or at least marketable entities and includes the consumer perspective. Unlike the planning perspective, it stresses the ability of agglomerations, despite their chosen location and existing environment, to influence their attractiveness and commercial success by using marketing instruments (e.g., Leo and Philippe, 2002; Finn and Louviere, 1996; Bearden, 1977; Gautschi, 1981; Nevin and Houston, 1980). So far, the research focus has been strongly on retailing, marketing and/or consumer behaviour issues regarding CAF and in particular MALs. However, an extended view of agglomeration marketing issues towards EAF can be found in publications dealing with 'Urban Place Marketing' or 'Town Centre Management'; for an extensive overview see Warnaby et al. (2002, 2004).

Nonetheless, the existing literature lacks empirical investigations on why consumers show an increasing preference towards CAF in contrast to EAF. In particular, it lacks findings on the relative impact of $\mathrm{AF}$ characteristics (influenceable by the agglomeration management) on the attractiveness of CAF compared to EAF from the consumers' point of view.

Based on this research position, this paper investigates the following research question: What AF characteristics impact the attractiveness of SST compared to MAL from the consumers' point of view? A more thorough understanding of the different determinants of attractiveness will contribute to answering the overall question "why do people shop where they shop' on an agglomeration format level (Woodside and Trappey, 1992). Consequently, it provides further understanding of the shift of market shares from SST to MAL and the 
identification of the competitive advantage of each format.

The structure of this paper is as follows: First, the SST is contrasted to MAL by discussing their generic similarities and differences. Furthermore, the two AF are compared according to their characteristics as perceived by consumers. Based on this discussion a conceptual framework and hypotheses are developed and presented to identify the relevant factors in terms of AF characteristics driving agglomeration attractiveness. Thereafter, the research design of the empirical study is explained and justified with respect to the research context and issues. This includes the sample description including demographic and behavioural aspects. Next is a discussion of the analysis and findings from the hypotheses testing with respect to findings in the literature. Possible practical implications, major limitations of the empirical study, and ideas for further research conclude the paper.

\section{COMPARISON BETWEEN SHOPPING STREETS AND SHOPPING MALLS}

\section{Generic similarities of agglomeration formats}

According to a frequently used dictionary definition the verb 'agglomerate' means "to form or be formed into a mass or a cluster" (Anonymous, 1999). This definition illustrates both the passive and active character of the related noun agglomeration; an agglomeration or cluster of objects can develop randomly or be constructed deliberately (Guy, 1995; Gilbert, 2003). In a commercial or retailing context such objects correspond to retail stores and other kind of outlets which are clustered or located nearby each other (Guy, 2007; Baker, 2006, Wrigley and Low, 2002). This phenomenon can be denoted as 'retail agglomeration'.

Regardless of the differences between particular agglomerations or formats the aim of retailers, who locate their stores nearby other stores, is to benefit from bundling and/or agglomeration effects (Oppewal and Holyoaka, 2004). Nelson (1958) calls this phenomenon 'cumulative attraction' and notes that "a given number of stores [...] will do more business if 
they are located adjacent or in proximity to each other then if they are widely scatted". Such synergies can be distinguished between those of benefit to retailers and/or to customers (Ghosh, 1986). Thus, it can be concluded that retail agglomerations are more than the sum of their parts, i.e. retail stores and other tenants.

From the retailer's point of view agglomeration effects result from 'co-opetition' amongst several stores at that location (Brandenburger and Nalebuff, 1996), i.e. they cooperate and compete with each other at the same time (Howard, 1997). Retailers benefit from using the same infrastructure or provision of infrastructural services such as regional traffic infrastructure, public transport systems, building stocks, public toilets, and cash dispensers. Single retailers can benefit from 'customer streams' or 'traffic' not necessarily generated by them (Ghosh, 1986; Dunne and Lusch, 1999). Finally, retailers and also non-retail tenants compete for, or appeal to, the same consumers making their trip there.

From the consumers' point of view the benefits in choosing an agglomeration when satisfying demand can be categorised as a convenience aspect to minimise shopping endeavours in a multi-purpose shopping trip and an entertainment aspect to use the agglomeration as a place to spend time being entertained or pampered by specific facilities such as restaurants, bars or cinemas (Reimers and Clulow, 2004; Kim, 2002; Dellaert et al., 1998).

\section{Conceptual and structural differences between shopping streets and shopping malls}

The basic differences between SST and MAL originate from the management concept behind MAL. A MAL is a cluster of stores located in single building planned, designed and built for retailing and retail-related issues; they are managed as a single unit by an institutionalised centre management (Levy and Weitz, 2006; Lambert, 2006; ICSC, 2004). One aim of owners, e.g. real estate or retail companies, and the management of MAL is to increases the attractiveness, synonymous for gravity and drawing power or preference over other AF to consumers, which should lead to opportunities for sales maximisation for its 
tenants. Consequently, the price or rent MAL tenants have to pay depends mostly on the attractiveness of the retail space and the sales volume they generate.

This perspective of attractiveness and sales maximisation dominates all strategic, tactical and operative management issues from the planning of the property to centre-marketing activities. The authority and power of the centre management is based on contracts with the tenants (Howard, 1997). Enhancement of the agglomeration attractiveness enables management to 'force' its tenants to participate in cooperative marketing efforts (Kang and Kim, 1999). Typical centre management tasks comprise:

- choosing tenants;

- making decisions regarding the location of tenants within the agglomeration;

- marketing activities such as cooperative advertising, promotion or public relations activities and organisation of events;

- coordinating infrastructure services such as security and cleaning services, opening hours, maintenance/repair works, decoration; and

- organising incoming and outgoing traffic, parking system and logistics.

SST can be regarded as a cluster of (retail) stores located along and close to a main street of district, town or city centres. In contrast to MAL, SST lack such a concerted management concept. This agglomeration format is found in urban areas that are not exclusively designed and managed in terms of commercial issues generally and retailing issues particularly (Bromley and Thomas, 1995). Several stakeholder groups, e.g. people living there, politicians and landlords can influence the development of this agglomeration environment (Warnaby and Medway, 2004). As a consequence the infrastructure of an SST differs to that of a MAL; for example in the availability of floor space for large scale retailers, architecture, traffic infrastructure and parking facilities.

City or place marketing and management concepts that aim to enhance the attractiveness of 
SST are based on the willingness of tenants to cooperate. However they lack a contractbased liability for participation and adherence to agreed strategies and activities as found in MAL (Reimers and Clulow, 2004, Warnaby and Medway, 2004; Warnaby et al., 2002, 2003, 2004). Tenants in SST generally try to maximise only their own attractiveness and consequently sales or profit while neglecting the importance to think and also act on a suprastore or agglomeration level.

\section{Differences from the consumers' perceptual point of view between shopping streets and shopping malls}

The structural and conceptual differences above imply distinct conscious or unconscious applications of retail (marketing) mix on an agglomeration level. This mix comprises the following elements in terms of retail marketing instruments,

- 'distribution', i.e. accessibility, parking, orientation and infrastructure;

- 'assortment and pricing', i.e. tenant mix, atmosphere and merchandise value; and

- 'communication', i.e. public relations, promotions and advertising (Anselmsson, 2006).

The single elements of the mix and the mix as a whole determine the agglomeration format's characteristics from the consumers' point of view (Frasquet et al., 2001; Kirmani and Baumgartner, 1999). The perception of the applied mix considerably affects consumers' evaluation of an agglomeration format's attractiveness. By focusing on the application of retail marketing instruments the major differences between SST and MAL can be summarised as follows (see Teller and Reutterer (2008), Frasquet et al. (2001), Finn and Lourviere (1996): 
Convenience in accessing agglomeration formats (accessibility and parking)

Convenience in reaching or accessing agglomerations depends on

- the temporal and spatial distance between the point of origin, mostly the household or the working place, and the agglomeration;

- the road network;

- $\quad$ the public transport system;

- parking facilities;

- $\quad$ use of means of transport; and

- situational factors such as daytime versus evening, traffic situations, and obstacles on the way.

The needs of consumers using a vehicle as a means of transport for shopping are consciously taken into account when planning and managing MAL. Peripheral located MAL can be accessed more easily because of the lack of inner-city traffic problems (Wrigley and Lowe, 2002; Warnaby et al., 2002, 2003, 2004). In general MAL has easy to access, costfree (partly) and sufficient parking facilities compared to SST. The central location of SST is less attractive for car-customers as parking fees must be paid and/or parking lots are not always available within or nearby the agglomeration. Parking facilities are mostly planned and operated by local authorities (in some cases by assigned private firms) who do not necessarily consider the needs of tenants or consumers of agglomerations. The traffic situation in total determines the convenience of reaching SST but also centrally located MAL.

Consumers who are not able, cannot afford or simply do not want to use or need cars for their shopping trips may find the central location more attractive (Reimers and Clulow, 2004; Gilbert, 2003). This is particularly the case for SST.

Capability to fulfil the defined (shopping) task (tenant mix, merchandise value, personnel)

The degree to which consumers are able to satisfy their wants and needs depends on the 
presence of tenants, including retail tenants and non-retail tenants such as bars, restaurants or cinemas (Teller and Reutterer, 2008; Reimers and Clulow, 2004). MAL are designed for a predefined tenant mix. This includes not only the variety and location of tenants but also the requirements of retail formats, in particular floor space (Whysall, 1995). Thus, large scale retail formats such as category killers or hypermarkets can be found in MAL to a higher degree compared to SST where floor space is provided in separate buildings (Guy, 1995). Such 'anchor stores' attract the highest or a higher share of customers compared to other smaller retail tenants (Levy and Weitz, 2006; Gilbert, 2003).

Control over the tenant mix by the agglomeration management makes it easier to focus on the preferences of the target group in MAL. SST lack such an influence on its tenant portfolio. Undesirable tenants like sex or second hand shops in low rental location can have a negative impact on the image and consequently the attractiveness of agglomerations. Overall, the price-value ratio, the assortment of goods and services offered and the type of sales-personnel in an agglomeration can be seen as a consequence of the tenants located within it. The tenant mix can be considered as the key source of AF attractiveness since it is the main prerequisite to fulfil the consumer task, e.g. shopping, food consumption but also entertainment (Van Kenhove et al., 1999).

\section{Enrichment and facilitation of the (shopping) task fulfilment}

Atmospheric stimuli in public places, including smell, music, decoration or agglomeration layout and temperature can be influenced in MAL to a higher degree, especially in enclosed MAL (Dennis, 2005). The sum of all atmospheric stimuli results in an overall AF atmosphere that provides enrichment and consequently an extension of the retention period of consumers. The atmosphere of SST cannot be influenced as much according to consumers' needs by agglomeration management. The atmospherics evolve naturally as a result of the urban location and the presence of tenants (Warnaby and Medway, 2004). However, the physical environment of a SST, e.g. in terms of an historic city centre or open-air character 
can contribute to a unique atmosphere which can not really be imitated by MAL.

The size and layout within agglomerations, depending on the size and number of tenants, can become problematic for consumers. MAL management tries to ease this (shopping) endeavour by providing a clear arrangement of tenants within the premises and setting up directories that enable consumers to easily target and access the tenants they seek. In addition, infrastructure services within MAL such as the provision of public toilets, cash dispensers and recreational areas to meet the expectations and demand of consumers, supports the fulfilment of the defined (shopping) tasks. On the contrary, the location of tenants in SST evolves over time and, thus, may not necessarily result in a clear arrangement of possible shopping targets for customers. In addition to that orientation guides are rarely found. Infrastructure services are rarely provided according to agglomeration consumers' views, but depend on the municipality or banks, respectively.

Table 1 provides an overview of the differences between SST and MAL. It is as a presentation of the typology criteria characterising the two formats. Thus it is possible that not every specific SST or MAL in the complex world of retailing fulfils all the criteria. Nonetheless, this discussion of differences is based on building typologies of retail formats where store types overlap in terms of chosen (typology) criteria but are similar for most of them (Levy and Weitz, 2006). 
Table 1: Differences between shopping streets and shopping malls

\begin{tabular}{|c|c|c|}
\hline $\begin{array}{l}\text { Agglomeration format } \\
\text { Distinctive criteria }\end{array}$ & MAL & SST \\
\hline \multicolumn{3}{|l|}{ Structural and conceptual differences } \\
\hline Ownership & $\begin{array}{l}\text { Owned by a commercial company, single } \\
\text { ownership of real estate }\end{array}$ & $\begin{array}{l}\text { No single ownership, scattered ownership } \\
\text { of real estate }\end{array}$ \\
\hline Agglomeration management & $\begin{array}{l}\text { Institutionalised and central (centre } \\
\text { management) }\end{array}$ & $\begin{array}{l}\text { Undertaken by the municipal, cooperative } \\
\text { and good will based (city/street } \\
\text { management) }\end{array}$ \\
\hline Cooperation between tenants & Contract based, obligatory & Good will based, voluntarily \\
\hline Location of agglomeration & Peripheral or central to (sub-)urban areas & Central to (sub-)urban areas \\
\hline Location of outlets & $\begin{array}{l}\text { Planned and determined by the centre } \\
\text { management }\end{array}$ & $\begin{array}{l}\text { Evolved, not directly determined or } \\
\text { influenceable by the agglomeration } \\
\text { management }\end{array}$ \\
\hline \multicolumn{3}{|l|}{ Instrumental differences } \\
\hline Accessibility & $\begin{array}{l}\text { Explicit consideration of and higher } \\
\text { convenience for consumers using the car } \\
\text { on shopping trips }\end{array}$ & $\begin{array}{l}\text { Higher convenience for consumers who } \\
\text { shop on foot or use public means of } \\
\text { transport }\end{array}$ \\
\hline Parking facilities & $\begin{array}{l}\text { - Designed for agglomeration customers' } \\
\text { needs } \\
\text { - enough \& free of charge }\end{array}$ & $\begin{array}{l}\text { - Dependent on environmental factors } \\
\text { (e.g. availability of space, local authorities) } \\
\text { - parking fees, limited availability }\end{array}$ \\
\hline Tenant mix & $\begin{array}{l}\text { Determined by the centre management } \\
\text { according to the needs of the target group }\end{array}$ & $\begin{array}{l}\text { Evolves over time and does not } \\
\text { necessarily correspond to the needs of the } \\
\text { target groups and the image of the } \\
\text { agglomeration }\end{array}$ \\
\hline Atmospheric stimuli & $\begin{array}{l}\text { Generated and influenced by the centre } \\
\text { management }\end{array}$ & $\begin{array}{l}\text { - Develop naturally } \\
\text { - hardly generated and influenced }\end{array}$ \\
\hline $\begin{array}{l}\text { Infrastructural services (opening } \\
\text { hours, toilets, cash dispensers } \\
\text { etc., orientation guides) }\end{array}$ & $\begin{array}{l}\text { Provided by the centre management } \\
\text { according to consumers' needs }\end{array}$ & $\begin{array}{l}\text { Provided by municipality or banks, } \\
\text { respectively }\end{array}$ \\
\hline $\begin{array}{l}\text { Marketing-related activities to } \\
\text { enhance AF attractiveness }\end{array}$ & $\begin{array}{l}\text { - Managed centrally } \\
\text { - compulsory participation of tenants }\end{array}$ & $\begin{array}{l}\text { - Cooperative } \\
\text { - voluntary participation }\end{array}$ \\
\hline
\end{tabular}

Sources: Alzubaidi et al., 1997; Dennis, 2005; Guy, 1995, 2007; Levy and Weitz, 2006; Wrigley and Low, 2002; Warnaby et al., 2002, 2003, 2004; Howard, 1997; Reimers and Clulow, 2004

It can be concluded that both similarities and differences, in particular in terms of the applied retail marketing instruments and mix, produce the characteristics of SST and MAL that are perceived and subsequently compared by consumers (Leo and Philippe, 2002).

\section{CONCEPTUAL FRAMEWORK}

The AF specific characteristics perceived by consumers provide distinct sources for evaluating attractiveness (Frasquet et.al., 2001). According to Teller and Reutterer (2008) the construct of AF attractiveness is operationalised by diverse dimensions: (1) satisfaction, 
(2) retention proneness and (3) patronage intention. In other words an agglomeration needs to be attractive, synonymous for preferable or favourable, at different stages of the buying process. Customers need to be satisfied to choose the agglomeration as a destination for the shopping trip; they should be willing to stay there as long as possible during their visits and should become loyal customers of the agglomeration. Teller and Reutterer (2008) provided empirical evidence for the selective character of the three dimensions from the customers' point of view. The evaluated attractiveness as a whole impacts the shopping behaviour e.g. the number of visits, the retention time and consequently the spending per visit (Anselmsson, 2006).

By taking into account notions from Finn and Lourviere (1996) and Teller and Reutterer (2008) and by considering these differences between SST and MAL nine characteristics, i.e. independent factors, can be considered as relevant for influencing the evaluated AF attractiveness, i.e. dependent factors. The characteristics account for the accessibility of the agglomeration, parking facilities, retail tenant mix, non-retail tenant mix, merchandise value, sales personnel, atmosphere, orientation within the agglomeration and infrastructure on site. All factors are operationalised by two or more indicators (see Appendix 1).

Figure 1 depicts the path model which serves as a framework for empirically investigating the effects of the nine AF characteristics on the attractiveness in different AF settings. Each of the 18 paths corresponds to a hypothesis proposing a positive and significant effect of one AF characteristic on one of the dimensions of attractiveness. Unlike the approach of Teller and Reutterer (2008) the moderating effect of the shopping situation is neglected in this paper. Thus, attractiveness is operationalised by satisfaction and patronage intention. 
Figure 1: Proposed effects (hypotheses) on agglomeration format attractiveness

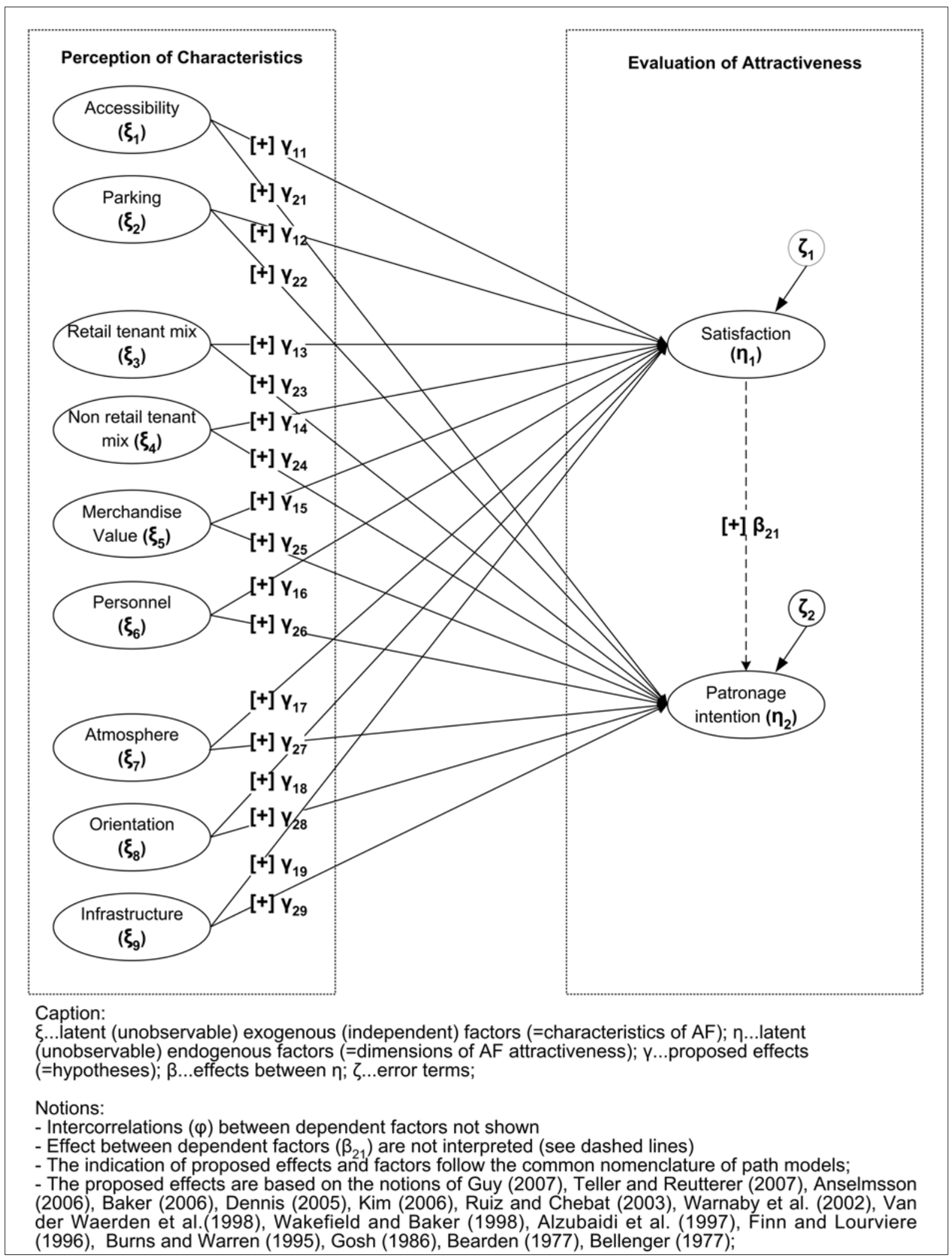


In order to identify the characteristics which are most closely related and so most influential for the evaluated AF attractiveness, i.e. determinants (Mayers and Alpert, 1968), and to compare them between SST and MAL the effects must be tested simultaneously for each AF. A statistical significance of a single effect indicates that an individual hypothesis should be accepted, meaning that the independent factor is relevant for changing the degree of attractiveness. The size of effects shows the relative importance between the factors. In other words, determinants of attractiveness are identified that are responsible for satisfying customers of the respective AF and attracting existing and prospective customers.

\section{EMPIRICAL STUDY}

\section{Investigated retail area}

To investigate the determinants of AF attractiveness a central European urban retail area, i.e. Vienna, was chosen. There, consumers can shop in more than thirty MAL and more than twenty SST. All MAL are enclosed and all SST are located in the main streets of the respective city districts. Two SST and two MAL can be regarded as super-regional (sSST, SMAL) whereas the rest have a more regional character (rSST, rMAL). All super-regional agglomerations contain three or more anchor tenants and appeal to a significant wider catchment area than their regional counterparts. The sMAL have a semi-peripheral location and thus appeal to a considerable share of customers using the car for their shopping trip. All agglomerations are connected to the high quality public transport system. The competition between SST and MAL can be regarded as intense. Unlike SSST, rSST have been steadily losing importance with respect to sales and number of powerful tenants.

The Vienna Chamber of Commerce has implemented a marketing initiative for all SST (for further details see WES, 2007). Their activities concentrate on public relations and selected promotion campaigns. The initiative suffers from the problem that (anchor) tenants owned by international retailers are sometimes reluctant to make (little) financial contribution and to 
participate to the cooperative marketing of the SST.

\section{Preliminary study}

In order to get a deeper understanding regarding the research topic, a qualitative exploratory study including three group discussions was conducted. In contrast to single (in-depth) interviews group discussions can be used to better analyse individual attitudes towards, opinions about and patronage behaviour towards AFs (Flick, 2006). The three groups represent different age segments of Viennese consumers: 16-25 years (9 participants), 2650 (9 participants) and older than 50 (6 participants). The distribution regarding gender and educational status in the population was considered within each group. All three discussions were led by two moderators and guided by an outline containing various discussion stimuli. The transcribed conversations were content-based coded and analysed by two people using the software package NVivo (N6). Thus, the guidelines proposed by Krueger (1998) and Richards (2002) were followed. The major findings can be summarised as follows:

- All participants were able to think and argue on an agglomeration level. They used the brand names of the MAL and the street names of the SST when discussing agglomeration issues.

- Almost all participants expressed their sympathy towards shopping in SST due to their historic and open-air character. Nonetheless, they undertook a self-critical perspective by reflecting their actual patronage behaviour, which was mostly in favour of MAL.

- Participants based their arguments regarding their shopping experiences on their most frequently visited SST or MAL. They identified a lack of comparability between 'big' and 'small' agglomerations, i.e. super-regional vs. regional SST and MAL.

- Besides the retail tenant mix, atmospheric stimuli of SST and the accessibility of MAL were discussed most intensively as determinants of the attractiveness within all three groups. 
Being aware of shortcomings of this qualitative research approach (e.g. limited (external) validity, the lack of objectivity and reliability), the findings formed the basis for the choice and the design of the main quantitative study and the development of the research instrument.

\section{Research method and instrument}

A survey approach was chosen for the main study and a self-administered, web-based questionnaire was developed following the suggestions of Grant et al. (2005). The main justification for that was that a large sample could be reached for reasonable costs and within a short period of time (llieva et al., 2002). The method used e-mails containing a motivation text and including a link to the questionnaire, sent to members of an online-panel, i.e. consumers older than 16 years, administered by a market-research company. Finally, a sample of 956 respondents was retrieved which can be considered as representative for the surveyed population with respect to gender and educational level.

Furthermore, the applied web-based survey technique enabled the researchers to control the answering and response process by including interactive elements to prevent item nonresponse and to check the quality of responses based on the observation of the total answering time and response process (Grant et al., 2005). Six questionnaires having an unreasonable answer time and monotonous ratings were excluded for analysis purposes, producing a final sample of 950 .

The questions and indicators were derived from the literature as discussed above and extended or modified according to the findings of three group discussions. By following Churchill's (1979) approach for developing and testing variables and constructs, the questionnaire had been previously applied in three extensive studies dealing with similar phenomena.

Due to the proposed model (see Figure 1) and the findings from the preliminary study it was 
decided to use an indirect questioning approach (Myers and Alpert, 1968; Bearden, 1977), i.e. the attractiveness and the characteristics were rated separately. The relationships between the dependent and independent factors were then investigated using Structural Equation Modelling. Based on this approach, the dramaturgy of the questionnaire was as follows: First, respondents were asked to choose from a comprehensive list of all MAL in Vienna the one they most frequently visit. Then they evaluated the attractiveness of, and their shopping behaviour in that preferred MAL, and rated the agglomeration's characteristics based on the indicators behind the factors in the model (see Appendix 1). The process was repeated for their most-frequently visited SST. By doing so, the respondents provided answers for those agglomerations of which they have the most extensive knowledge and experience. Finally, they had to characterise themselves based on demographic variables.

\section{RESULTS}

\section{Characterisation of respondents}

\section{Demographics}

The sample $(n=950)$ consists of a slightly higher share of women $(54.5 \%)$ compared to men. Referring to the population of Vienna the average age of respondents (mean $(\mu)=37.5$ years; standard deviation $(\sigma)=11.3)$ proved to be low (Statistik Austria, 2007). The older consumer segment (60 and older) was not covered to a satisfactory degree which was due to the choice of the research medium (internet) and the inherent non-coverage error (Grant et al., 2005).

The educational level can be considered to be high (a-level=25.4\%; university degree $=12.9 \%)$. On average the respondents live in households with two persons $(\sigma=.9)$ and have a monthly net-income of EUR $1,413.47(\sigma=1,015.43)$. An average of $1.3(\sigma=.9)$ cars are available in each household. These figures correspond to the characteristics of the population of the capital city of Austria (Statistik Austria, 2007). 


\section{Agglomeration format patronage}

Out of the sets of most frequently visited MAL and SST specified by the respondents, four AF were identified. Each of them includes agglomerations which are comparable with respect to size, tenant mix structure, type of location and accessibility. This distinction corresponds with the findings from the group discussions and can be seen from Table 2:

Table 2: Agglomeration format patronage

\begin{tabular}{lcccc}
\hline \multicolumn{1}{c}{$\begin{array}{c}\text { Agglomeration Format (AF) } \\
\text { Characterisation }\end{array}$} & $\begin{array}{c}\text { Super-regional } \\
\text { mall (sMAL) }\end{array}$ & $\begin{array}{c}\text { Regional } \\
\text { (rMAL) }\end{array}$ & $\begin{array}{c}\text { Super-regional } \\
\text { shopping street } \\
\text { (sSST) }\end{array}$ & $\begin{array}{c}\text { Regional } \\
\text { shopping street } \\
\text { (rSST) }\end{array}$ \\
\hline $\begin{array}{l}\text { Number (share) of respondents } \\
\text { patronising the AF }\end{array}$ & $380(40 \%)$ & $451(47.5 \%)$ & $602(63.4 \%)$ & $227(23.9 \%)$ \\
$\begin{array}{l}\text { Number of respondents not patronising } \\
\text { either of the MAL or SST formats }\end{array}$ & \multicolumn{2}{c}{$119(12.5 \%)$} & & $121(12.7 \%)$ \\
$\begin{array}{l}\text { Number of similar agglomerations } \\
\text { subsumed under the AF }\end{array}$ & 2 & 12 & 2 & 9 \\
\hline
\end{tabular}

The share of stated preferences suggests a clear preference towards a small number of super-regional agglomerations, in particular sSST. Furthermore, the low importance of rSST is also evident. Finally, it is worth mentioning that the highest overlap between patrons of different AF is between the sSST and rMAL (31\%) and between sSST and SMAL (24\%).

\section{Shopping behaviour}

The respondents' shopping or visiting behaviour to the four AF is analysed in Table 3. By focusing on the main (significant) differences it can be seen that patrons of the superregional AF overcome a higher spatial and temporal distance when going there, visit these agglomerations less often, spend more money for goods and services, shop in more outlets and stay longer at each visit compared to those of the regional AF. The preferred means of transport for shopping is the car for sMAL patrons and the subway, the tramway or bus for rMAL and SSST patrons. rSST customers most often choose to walk to their shopping destination.

Whilst the level of spending for food and entertainment is similar in both MAL formats, the total amount is smaller in the rSST compared to the sSST. Nonetheless, the relative amount, 
i.e. the share of the total spending, is higher in rSST. The highest share of spend can be found in SMAL and the lowest in the rMAL. Spend is about the same for both SST formats.

Table 3: Characterisation of respondents' shopping behaviour

\begin{tabular}{|c|c|c|c|c|c|c|}
\hline $\begin{array}{l}\text { Respondent groups } \\
\text { Characterisation }\end{array}$ & $\begin{array}{c}\text { sMAL }(n=380) \\
\mu(\sigma) \text { or } \%\end{array}$ & $\begin{array}{c}\text { rMAL }(n=451) \\
\mu(\sigma) \text { or } \%\end{array}$ & Diff. & $\begin{array}{c}\text { sSST }(n=602) \\
\mu(\sigma) \text { or } \%\end{array}$ & $\begin{array}{c}\text { rSST }(n=227) \\
\mu(\sigma) \text { or } \%\end{array}$ & Diff. \\
\hline $\begin{array}{l}\text { Shopping (visiting) } \\
\text { frequency per month }\end{array}$ & $2.2(2.3)$ & $3(3.3)$ & $* * \star A$ & $3(3.6)$ & $4.5(5.3)$ & $* * A$ \\
\hline $\begin{array}{l}\text { Spending }(€) \text { for products } \\
\text { per visit }\end{array}$ & $116(111)$ & $65.7(77.1)$ & $* * \star A$ & $96.4(95.6)$ & $65.3(108.3)$ & $* * * A$ \\
\hline $\begin{array}{l}\text { Spending }(€) \text { for } \\
\text { food/entertainment per } \\
\text { visit }\end{array}$ & $15.5(21.6)$ & $15.1(15.2)$ & - & $16.3(14)$ & $12.7(10.8)$ & $* \star A$ \\
\hline $\begin{array}{l}\text { Retention time ( } \min ) \text { per } \\
\text { visit }\end{array}$ & $132(62.6)$ & $81.9(51.2)$ & $\star * \star A$ & $127.2(61)$ & $74.4(47.1)$ & $* * * A$ \\
\hline $\begin{array}{l}\text { Shops visited per trip on } \\
\text { average }\end{array}$ & $5.8(3.9)$ & $3.5(2)$ & $* * * A$ & $5.5(4.1)$ & $3.5(2.4)$ & $* *{ }^{A}$ \\
\hline $\begin{array}{l}\text { Share of wallet (share of } \\
\text { spending in the } \\
\text { agglomeration/total } \\
\text { spending (for products) }\end{array}$ & $24.7(22.8)$ & $18.8(19.5)$ & $* \star A$ & $21.6(20.4)$ & $21.1(20.6)$ & - \\
\hline $\begin{array}{l}\text { Spatial distance from } \\
\text { starting point }(\mathrm{km})\end{array}$ & $12.9(11.4)$ & $5.3(5.5)$ & $* * * A$ & $8(7.9)$ & $4.1(5.2)$ & $\star \star \star \star A$ \\
\hline $\begin{array}{l}\text { Temporal distance from } \\
\text { starting point (min) }\end{array}$ & $20(11.7)$ & $14.7(8.8)$ & $* * * A$ & $20.4(13.6)$ & $12.7(9.8)$ & $* * * A$ \\
\hline $\begin{array}{l}\text { Used means of transport } \\
\text { to get to the } \\
\text { agglomeration (Top 3) }\end{array}$ & $\begin{array}{c}\text { Car }=80 \% \\
\text { Public } \\
\text { transport }=17.6 \% \\
\text { On foot }=1.1 \%\end{array}$ & $\begin{array}{c}\text { Public transport } \\
=42.8 \% \\
\text { Car }=39.7 \% \\
\text { On foot }=15.7 \%\end{array}$ & $\star \star \star * B$ & $\begin{array}{c}\text { Public transport } \\
\quad=59 \% \\
\text { Car }=23.2 \% \\
\text { On foot }=15.9 \%\end{array}$ & $\begin{array}{c}\text { On foot }=42.2 \% \\
\text { Public } \\
\text { transport. }=28.9 \% \\
\text { Car }=28 \%\end{array}$ & ${ }^{* * * B}$ \\
\hline $\begin{array}{l}\text { Notes } \\
\text { sMAL...super-regional ma } \\
\text { n...sample size; } \mu . . \text { mear } \\
\text {-...not significant ( } p>.05) \text {; }\end{array}$ & $\sigma \ldots . . s t$ & ; Diff. & & etwe & - & \\
\hline
\end{tabular}

\section{Perception of AF characteristics and evaluation of attractiveness}

Lastly, the differences in ratings for the characteristics and attractiveness of the four AF are presented (see $\mu$ and $\sigma$ of the indicators representing the eleven factors in Appendix 1). It can be seen that the super-regional AF are evaluated as more attractive than the regional ones, i.e. respondents are more satisfied with and more likely to patronise these AF in the future. The worst ratings can be found with the rSST.

The retail and the non-retail tenant mix in the SMAL and the SSST are also rated higher, whereas the accessibility of and the orientation are seen to be better in rMAL and rSST. Parking conditions and infrastructural services are rated highest in both MAL formats. The atmosphere is regarded to be more pleasant in SSST and rMAL and the merchandise value in the other two formats. The ratings for the personnel prove to be similar for all four formats. 
The results from the behavioural and perceptual characterisation reflect the competitive environment in this central European retail market. They indicate the strength and weaknesses of each AF but also the dominant position of super-regional agglomerations and the lowest importance of rSST.

\section{Analysis}

The model was tested for all four settings separately. Structural equation modelling using the statistical software AMOS 5.0 was applied; a comprehensive overview regarding this analysis method can be found in Hair et al. (1998), Kline (2005) or Byrne (2001).

As a basic prerequisite, the local fit of the (endogenous and exogenous) measurement models, i.e. the measurement validity and the global fit of the analyzed model, i.e. the degree of congruency between the proposed model and the empirical data, were tested. Suggestions from Churchill (1979) and Bagozzi and Yi (1988) were followed and confirmatory factor analyses for each of the measurement models were calculated (see Appendix 1). All constructs have a good internal consistency with Cronbach's $\alpha$ around or above 0.70 (Fornell and Larcker, 1981). Indices showing constructs' composite reliability ( $\rho>$ $0.60 ; \mathrm{AVE}>0.50)$ and the discriminant validity $(F L R<1)$ also meet the recommended cut-off criteria (Bagozzi and Yi, 1988; Fornell and Larcker, 1981). Consequently, the local fit of the measurement models can be regarded as satisfactory.

The global fit was tested by calculating and interpreting indices showing the absolute, incremental and parsimonious fit of each model (Hu and Bentler, 1991, 1999; Anderson and Gerbing, 1988). Table 4 includes the values of the single indices which again meet recommended requirements. For all four AF groups it can be concluded that the empirical data fit of the proposed model to a satisfactory degree. 


\section{Determinants of agglomeration format attractiveness}

The presentation of results for each model comprises both the identification of significant effects, i.e. significance of t-values, and the comparison of the effects based on their relative impact, i.e. value of standardised coefficients $(\mathrm{Y})$ as set out in Table 4. A significant positive effect denotes the acceptance of a respective hypothesis whereas non-significant impacts between dependent and independent factors indicate a rejection of that hypothesis.

Table 4: Determinants of agglomerations' attractiveness

\begin{tabular}{|c|c|c|c|c|c|}
\hline $\begin{array}{l}\text { Hypo- } \\
\text { thesis }\end{array}$ & $\begin{array}{l}\text { Effects between exogenous }(\xi) \text { and endogenous } \\
\text { factors }(\eta)\end{array}$ & $\begin{array}{c}\text { sMAL model } \\
n=380 \\
\gamma_{\text {sMAL }}\end{array}$ & $\begin{array}{c}\mathrm{rMAL} \text { model } \\
\mathrm{n}=451 \\
\mathrm{Y}_{\mathrm{rMAL}}\end{array}$ & $\begin{array}{c}\text { sSST model } \\
n=602 \\
\gamma_{\text {sSST }}\end{array}$ & $\begin{array}{c}\text { rSST model } \\
n=227 \\
\gamma_{\text {rSST }}\end{array}$ \\
\hline $\mathrm{H}_{11} / \mathrm{Y}_{11}$ & Accessibility $\rightarrow$ Satisfaction & - & - & $.133^{\star \star \star}$ & - \\
\hline $\mathrm{H}_{21} / \mathrm{Y}_{21}$ & Accessibility $\rightarrow$ Patronage intention & - & $.083^{*}$ & - & - \\
\hline $\mathrm{H}_{12} / \mathrm{Y}_{12}$ & Parking $\rightarrow$ Satisfaction & - & - & - & - \\
\hline $\mathrm{H}_{22} / \gamma_{22}$ & Parking $\rightarrow$ Patronage intention & - & - & - & - \\
\hline $\mathrm{H}_{13} / \mathrm{Y}_{13}$ & Retail tenant mix $\rightarrow$ Satisfaction & $.257^{\star \star \star}$ & $.487^{* \star \star}$ & $.423^{\star * \star}$ & $.288^{*}$ \\
\hline $\mathrm{H}_{23} / \gamma_{23}$ & Retail tenant mix $\rightarrow$ Patronage intention & $.113^{*}$ & $.169^{* *}$ & $.385^{\star \star *}$ & - \\
\hline $\mathrm{H}_{14} / \mathrm{Y}_{14}$ & Non-retail tenant mix $\rightarrow$ Satisfaction & - & - & - & $.322^{*}$ \\
\hline $\mathrm{H}_{24} / \mathrm{Y}_{24}$ & Non-retail tenant mix $\rightarrow$ Patronage intention & - & - & - & - \\
\hline $\mathrm{H}_{15} / \mathrm{Y}_{15}$ & Merchandise value $\rightarrow$ Satisfaction & - & - & - & - \\
\hline $\mathrm{H}_{25} / \mathrm{Y}_{25}$ & Merchandise value $\rightarrow$ Patronage intention & - & - & - & - \\
\hline $\mathrm{H}_{16} / \mathrm{Y}_{16}$ & Personnel $\rightarrow$ Satisfaction & $.156^{*}$ & - & - & $.180^{\star \star}$ \\
\hline $\mathrm{H}_{26} / \mathrm{Y}_{26}$ & Personnel $\rightarrow$ Patronage intention & - & - & - & - \\
\hline $\mathrm{H}_{17} / \mathrm{Y}_{17}$ & Atmosphere $\rightarrow$ Satisfaction & $.402^{\star * \star}$ & $.397^{\star \star \star}$ & $.342^{\star \star \star}$ & $.227^{\star \star}$ \\
\hline $\mathrm{H}_{27} / \mathrm{Y}_{27}$ & Atmosphere $\rightarrow$ Patronage intention & $.150^{*}$ & $.115^{*}$ & - & - \\
\hline $\mathrm{H}_{18} / \mathrm{Y}_{18}$ & Orientation $\rightarrow$ Satisfaction & - & - & - & - \\
\hline $\mathrm{H}_{28} / \mathrm{Y}_{28}$ & Orientation $\rightarrow$ Patronage intention & - & - & - & - \\
\hline $\mathrm{H}_{19} / \mathrm{Y}_{19}$ & Infrastructure $\rightarrow$ Satisfaction & - & - & - & - \\
\hline $\mathrm{H}_{29} / \gamma_{29}$ & Infrastructure $\rightarrow$ Patronage intention & - & - & - & - \\
\hline$\beta_{21}$ & Satisfaction $\rightarrow$ Patronage intention & $.553^{\star * *}$ & $.575^{\star \star \star}$ & $.438^{\star \star \star}$ & $.682^{\star \star \star}$ \\
\hline \multicolumn{2}{|c|}{ Global fit $\quad$ Measures (cutoff value) } & & & & \\
\hline Absolute fit & RMSEA $(<.08)$ & .053 & .051 & .055 & .063 \\
\hline Incremental fit & $\mathrm{TLI} / \mathrm{CFI}(>.9 />.9)$ & $.927 / .941$ & $.938 / .949$ & $.928 / .942$ & $.917 / .932$ \\
\hline \multicolumn{2}{|c|}{ Parsimony fit $\quad$ Normed $\chi^{2}(\mathrm{CMIN} / \mathrm{df})(<3)$} & 2.061 & 2.189 & 2.805 & 1.909 \\
\hline \multicolumn{6}{|c|}{$\begin{array}{l}\text { Notions: } \\
\text { Squared multiple correlations }\left(r^{2}\right) \text { : sMAL: } \eta_{1}=.475 ; \eta_{2}=.547 ; \text { rMAL: } \eta_{1}=.491 ; \eta_{2}=.652 ; \text { sSST: } \eta_{1}=.450 ; \eta_{2}=.643 ; \text { rSST: } \eta_{1}=.577 \text {; } \\
\eta_{2}=.701\end{array}$} \\
\hline
\end{tabular}

In all four models a considerable degree of variance of the dependent factors (satisfaction $\left(\eta_{1}\right)$ and patronage intention $\left(\eta_{2}\right)$ is explained by the independent factors (AF-characteristics $\left(\xi_{1}-\xi_{9}\right)\left(r^{2}>.48\right)$ (Byrne, 2001). However, only a limited number of effects prove to be significant $(p<.5)$. More specifically, five hypotheses out of eighteen can be confirmed in the MAL models and four in the SST models. 
In the sMAL the most important factor is the 'atmosphere' $\left(\gamma_{17}, \gamma_{27}\right)$. It affects both dimensions of attractiveness and has the highest impact on satisfaction compared to all the other determinants. Secondly, the 'retail tenant mix' is of major importance $\left(\mathrm{\gamma}_{13}, \mathrm{Y}_{23}\right)$. Again both effects on attractiveness are significant and considerable. Apart from these only 'personnel' $\left(\bigvee_{16}\right)$ has a significant but low impact.

By focusing on the rMAL it can be seen that the effects are similar with respect to the two most important factors $\left(\mathrm{Y}_{13}, \mathrm{Y}_{23}, \mathrm{Y}_{17}, \mathrm{Y}_{27}\right)$; 'tenant mix' has the highest impact in that setting. In addition to these determinants, 'accessibility' $\left(\mathrm{\gamma}_{21}\right)$ shows a significant but low effect on patronage intention.

In SSST the 'tenant mix' $\left(\mathrm{Y}_{13}, \mathrm{Y}_{23}\right)$ again plays an important role. The coefficients are both significant and in total the highest for all four settings. 'Atmosphere' $\left(\gamma_{17}\right)$ has a significant and considerable impact only on satisfaction. Like the rMAL 'accessibility' $\left(\mathrm{\gamma}_{21}\right)$ is of low but significant importance, but affects only satisfaction.

The results for the rSST show considerable differences compared to the other AF. The most important determinant is the 'non-retail tenant mix' $\left(\gamma_{14}\right)$, although it affects only one dimension of attractiveness. Thereafter, 'retail tenant mix' $\left(\mathrm{V}_{13}\right)$ and 'atmosphere' $\left(\mathrm{V}_{17}\right)$ are the next most important ones, but they also only affect satisfaction. The same impact for 'personnel' $\left(\mathrm{V}_{16}\right)$ can be found as with to the sMAL.

By drawing attention to these parameters which are not significant and consequently to these factors that play no role in affecting attractiveness it can be concluded that 'parking', 'merchandise value', 'orientation' and also 'infrastructure' have no direct effect on the endogenous factors. 
Finally, it is worth mentioning that the characteristics of AF should not be regarded as being totally independent. By investigating the relationships amongst them (intercorrelation values $\varphi)$ which are not depicted in the model, it can be seen that most of them are significant $(p>.5)$. The highest intercorrelation $\left(\varphi_{\xi}>5\right)$ in all four settings can be found between the two tenant mix factors, between 'personnel' and 'atmosphere' and between 'orientation' and 'infrastructure'.

\section{Discussion}

The two groups of AF differ with respect to their management and marketing concepts. Furthermore, the structure and characteristics of all four AF are diverse. This is reflected in the distinct perception of their characteristics by customers and different evaluated levels of attractiveness (see Appendix 1). Nevertheless, the results suggest a homogenous picture towards the two major or first-order determinants of attractiveness $(y>.25$; Cohen, 1988) for all four AF.

The set of retail tenants has the highest relative importance. AF benefit most from the "cumulative retail attraction" (Nelson, 1958), whether the tenant mix is planned and/or influenced by the agglomeration management or not. Consequently, the degree to which consumers see the potential of an AF to satisfy bundles of wants and needs in one place, determines the satisfaction with and (except for rSST) the patronage intention towards AF.

By identifying the other most important factors, it can be concluded that visiting an agglomeration is about more than gathering products and services. The 'invisible shopping environment' in terms of sets of atmospheric stimuli shows a considerable impact in particular in MAL formats. However, this factor is only related to satisfaction in the two SST formats, as atmospheric stimuli, e.g., temperature, decoration, music, odour etc., cannot be influenced to the same degree compared to the MAL formats. These two major determinants 
cannot be seen to be independent, since retail tenants which are an integrated part of agglomerations also contribute to the overall atmosphere.

As with previous literature, which mostly focus on single agglomerations and in particular MAL (e.g., Teller and Reutterer, 2008; Anselmsson, 2006; Ruiz et al., 2003; Leo and Philippe, 2002; Bearden, 1977; Bellenger et al., 1977), it can be concluded that the tenant mix and the atmosphere are the most important factors for all four AF investigated in this study. The only additional major determinant was identified in the rSST model. There the notions of Reimers and Clulow (2004) regarding the 'non retail function' of agglomerations can be supported since the non-retail tenant mix, e.g., bars, restaurants or cinemas, is of importance in explaining satisfaction.

The second-order determinants have a significant, low $(\gamma<.15$; Cohen, 1988) and selective impact on either dimension of attractiveness. 'Accessibility' shows minor relevance for the patronage intention regarding rMAL and satisfaction with sSST. Thus, the notions of e.g. Reimers and Clulow (2004), Ruiz et al. (2003) and Alzubaidi et al. (1997) can be confirmed for these AF. These two AF have the largest overlap of patrons which most often use the public transport system on their shopping trips. 'Personnel' determines satisfaction in both sMAL and rSST; this supports the findings from Anselmsson (2006) and Leo and Philippe (2002). The share of small retail formats where personal selling (unlike self service oriented formats) is a crucial element of the retail mix is higher here than compared to the other AF. Overall, these second order determinants can be seen as AF specific opportunities to increase attractiveness, although they have a comparatively low impact compared to the tenant mix or the atmosphere.

Those factors related with shopping convenience, i.e. accessibility (sMAL and rSST), parking, orientation and infrastructure, do not seem to provide potential to change the attractiveness of the investigated AF. This contradicts findings from several authors, e.g. Van 
der Waerden et al. (1998), Alzubaidi et al. (1997), Reimers and Clulow (2004), Oppewal and Holyoake (2004) and Burns and Warren (1995). An isolated view of these factors may result in a 'convenience myopia'. This can be explained by comparing the results from the model with the univariate results from the factor ratings. Although the 'accessibility' of the rSST and the 'orientation' of the rMAL is rated best compared to the respective other $\mathrm{AF}$, their attractiveness is evaluated comparably worse. Whilst 'parking' and 'infrastructure' in sSST and 'orientation' in SMAL are seen to be suboptimal, the attractiveness of these two AF is rated high. This leads to the conclusion that weaknesses of AF regarding those factors which show no (significant) impact on the attractiveness can be compensated for by those factors which have been identified as determinants. In contrast to that, weaknesses regarding the determinant characteristics can not be mitigated by the identified non-significant factors.

\section{PRACTical implications}

The relative importance of the nine characteristics shows threats and opportunities for the agglomeration management of AF. The major problem of SST, and in particular rSST, is that the retail tenant mix can not be controlled. Consequently the attractiveness can rarely be influenced to the same degree as in MAL formats. This clearly indicates an uneven competition between MAL and SST. Referring back to the differences between the two groups of AF, a simple imitation of the centre management concept proves to be difficult.

Even so, SST management or marketing should approach and motivate potential retail tenants. This would enrich the retail portfolio and in terms of rSST the non-retail portfolio. This also includes convincing retailers to maintain their store location within a SST. In MAL for examples anchor or attractive tenants are motivated to locate or retain their location by charging them no or comparable little rental fee. Furthermore, the accentuation of the 'natural' atmosphere of SST should be considered as an important management task. In rSST retailers need to be aware that their sales personnel contribute to the AF attractiveness 
to a significant degree. In contrast to that, the improvement of accessibility for customers using the car, parking facilities and the provision of public toilets, cash dispensers or even orientation guides need to be seen as a secondary issue since they do not compensate for a suboptimal tenant mix or atmosphere.

\section{LIMITATIONS AND OUTLOOK FOR FURTHER RESEARCH}

The research suffers from some limitations. They can be differentiated between those emerging from the applied research method in general and the selected retail environment in particular.

In terms of the applied method, the survey can be characterised as an 'in vitro' approach (Teller and Reutterer, 2008). Questions were answered independent of an actual buying or shopping trip situation and therefore neglected all situational effects. Thus, the retrieved information can be seen as an average picture towards the perception of actually visited shopping sites, but it neglects the moderating effect of e.g. the fulfilment of diverse shopping tasks (Van Kenhove et al., 1999). Further, the choice of the internet as the research medium leads to a non-coverage error of the surveyed population. Consequently, the external validity is limited to those consumers younger than 60 years.

The retail environment chosen has several characteristics which are on one hand unique and on the other representative for typical urban Central European areas, e.g. type of agglomerations and AF, consumer characteristics, and local shopping behaviour. A replication of this study in other retail areas might lead to different results. Additionally, no distinction was made between various groups of consumers based on their demographic, psychographic and behavioural characteristics. All these differences could also have moderating effect on the investigated relationships. 
Lastly, the number of factors and indicators are not all-embracing when focusing on either of the two AF types exclusively; they were chosen for comparability. Promotional, advertising and public relations activities or information desks are rarely found in SST, thus these variables were not considered in the model (Anselmsson, 2006).

Based on the practical relevance of the topic, the results and the stated limitations, a wider research area can be suggested. This potential research agenda should include more indepth investigation of intra- and inter-AF competition considering other agglomeration types, such as street markets or scattered evolved AF, entertainment or factory outlet centres. Also, a replication of this study should focus on national or regional differences and more rural retail areas where AF types differ from their urban counterparts. A stronger consideration of behavioural variables within the model such as spending or retention time would give further in-depth answers to the question 'why do consumers shop in different kind of agglomeration formats'. Finally, the empirical results suggest that agglomeration planning issues create the prerequisite or the necessary conditions but that agglomeration marketing issues represent the ultimate driver for attractiveness and consequently the success of a location or AF. Thus, further research should provide a stronger consideration of cooperative marketing issues and of the consumer perspective regarding AF.

\section{REFERENCES}

Alzubaidi, H., Vignali, C., Davies, B. J. and Schmidt, R. A. (1997) 'Town centre versus out-oftown shopping: a consumer perspective', International Journal of Retail \& Distribution Management, 25(2), pp. 78-89.

Anderson, J.C. and Gerbing, D.W. (1988) 'Structural equation modeling in practice: A review and recommended two-step approach', Psychological Bulletin, 103(3), pp. 411-423.

Anonymous (1999) Collins English Dictionary, (Glasgow: Harper Collins Publishers).

Anselmsson, J. (2006) 'Sources of customer satisfaction with shopping malls: A comparative 
study of different customer segments', International Review of Retail, Distribution and Consumer Research, 16(1), pp. 115-138.

Arentze, T.A., Oppewal H. and Timmermans, H.J.P. (2005) 'A multipurpose shopping trip model to assess retail agglomeration effects', Journal of Marketing Research, 42(2), pp. 109-115.

Arentze, T. A. and Timmermans, H. J. P. (2001) 'Deriving performance indicators from models of multipurpose shopping behavior', Journal of Retailing and Consumer Services, 8(6), pp. 325-334.

Bagozzi, R. P. and Yi, Y. (1988) 'On the evaluation of structural equation models', Journal of the Academy of Marketing Science, 16(1), pp. 74 -94.

Baker, R. G. V. (2006) Dynamic trip modelling. From shopping centres to the Internet, (Dordrecht, Springer).

Bearden, W. O. (1977) 'Determinant attributes of store patronage - Downtown versus outlying shopping centers', Journal of Retailing, 53(2), pp. 15-22.

Bellenger, D. N., Robertson, D. H. and Greenberg, B. A. (1977) 'Shopping center patronage motives', Journal of Retailing, 53(2), pp. 29-38.

Berman, B. and Evans, J. R. (2007) Retail management. A strategic approach, (Upper Saddle River NJ, Pearson Prentice Hall).

Brandenburger. A. and Nalebuff, B. (1996) Co-opetition (New York: Doubleday).

Bromley, R. D. F. and Thomas, C. J. (1995) 'Small town shopping decline: dependence and inconvenience for the disadvantaged', International Review of Retail, Distribution and Consumer Research, 5(4), pp. 433-456.

Burns, D. J. and Warren, H. B. (1995) 'Need for uniqueness: Shopping mall preference and choice activity', International Journal of Retail \& Distribution Management, 23(12), pp. 4-12.

Byrne, B. M., (2001) Structural equation modeling with AMOS. Basic concepts, applications, and programming, (Mahwah (New Jersey), London: Lawrence Erlbaum Associates).

Churchill, G. A. (1979) 'A paradigm for developing better measures of marketing constructs', 
Journal of Marketing Research, 16(1), pp. 64-73.

Cohen, J. (1988) Statistical power analysis for the behavioral sciences, (New York: Academic Press).

CWHB (Cushman \& Wakefiled Healey \& Baker) (2005) Shopping centre development European overview. October 2005. Online: http://www.cushmanwakefield.com /cwglobal/docviewer/SCDR\%20-0European\%200verview,\%200ct\%2005. pdf?id=ca2300094\& repositoryKey=CoreRepository\&itemDesc=document.

Dellaert, B. G. C., Arentze, T. A., Bierlaire, M., Borgers, A. W. J. T. and Harry J. P. (1998) 'Investigating consumers' tendency to combine multiple shopping purposes and destinations', Journal of Marketing Research, 35(2), pp. 177-188.

Dennis, C. (2005) Objects of Desire. Consumer behaviour in shopping centre choices, (Houndmills: Palgrave Macmillan).

Dennis, C., Marsland, D., Cockett, T., (2002) 'Central place practice: shopping centre attractiveness measures, hinterland boundaries and the UK retail hierarchy', Journal of Retailing and Consumer Services, 9(4), pp. 185-199.

Dunne, P. and Lusch, R. F. (1999) Retailing, (Fort Worth et al.: The Dryden Press).

Finn, A. and Louviere, J. J. (1996) 'Shopping center image, consideration, and choice: anchor store contribution', Journal of Business Research, 35(3), pp. 241-251.

Flick, U. (2006) An introduction to qualitative research, (London: Sage Publications).

Fornell, C. and Larcker, D. F. (1981) 'Evaluating structural equation models with unobservable variables and measurement error', Journal of Marketing Research, 18 (1), pp. 39-40.

Frasquet, M., Gil, I. and Mollá, A. (2001) 'Shopping-centre selection modelling: a segmentation approach', International Review of Retail, Distribution and Consumer Research, 11(1), pp. 23-38.

Gautschi, D. A. (1981) 'Specification of patronage models for retail center choice', Journal of Marketing Research, 18(2), pp. 162-174.

Ghosh, A. (1986) 'The value of a mall and other insights from a revised central place model', 
Journal of Retailing, 62(1), pp. 79-97.

Gilbert, D. (2003) Retail marketing management, (Harlow: Financial Times Prentice Hall).

Grant, D. B., Teller, C., Teller, W. (2005) 'Hidden' opportunities and benefits in using webbased business-to-business surveys', International Journal of Market Research, 47(6), pp. 641-666.

Guy, C. M., (1995) The retail development process. Location, property and planning, (London: Routledge).

Guy, C. M., (2007) Planning for retail development. A critical view of British experience, (London: Routledge).

Hair, J. F., Anderson, R. E., Tatham, R. L., Black, W. C. (1998) Multivariate data analysis, (Upper Saddle River, New Jersey: Prentice Hall).

Howard, E. (1997) 'The management of shopping centres: conflict or collaboration?' International Review of Retail, Distribution and Consumer Research, 7(3), pp. 263-285.

Hu, L. and Bentler, P. M. (1991) 'Fit indices in covariance structure modelling: sensitivity to underparameterized model misspecification', Psychological Methods, 3(4), pp. 425453.

Hu, L. and Bentler, P. M. (1999). 'Cutoff criteria for fit indexes in covariance structure analysis: Conventional criteria versus new alternatives', Structural Equation Modeling, 6(1), pp. 1-55.

ICSC (International Council of Shopping Centers) (2004) ICSC shopping center definitions. basic configurations and types for the United States, Online: http://www.icsc.org/ srch/lib/USDefinitions.pdf

llieva, J., Baron, S. and Healey, N. M. (2002) 'Online surveys in marketing research: Pros and cons', International Journal of Market Research, 44(3), pp. 361-376.

Ingene, C. A. (1984) 'Productivity and functional shifting in spatial retailing: Private and social perspectives', Journal of Retailing and Consumer Services, 60(3), pp. 15-26.

Jewell, N. (2001) 'The fall and rise of the British mall', Journal of Architecture, 6 (4), 317-378.

Kang, J. and Kim, Y.-K., (1999) 'Role of entertainment in cross-shopping and in the 
revitalization of regional shopping centers', Journal of Shopping Center Research, 6(2), pp. 41-71.

Kim, H.-S. (2006) 'Using Hedonic and Utilitarian Shopping Motivations to Profile Inner City Consumers', Journal of Shopping Center Research, 13(1), pp. 57-79.

Kim, Y.-K. (2002) 'Consumer value: An application to mall and Internet shopping', International Journal of Retail \& Distribution Management, 30(11/12), pp. 595-602.

Kirmani, A., Baumgartner, H., (1999) 'Special session summary: Perceived quality and value, satisfaction and loyalty: New insights into processes underlying some familiar constructs', Advances in Consumer Research, 26, p. 598.

Kline, R. B., (2005) Principles and practice of structural equation modeling, (New York, London: The Guilford Press).

Krueger, R. A. (1998) Developing questions for focus groups. Focus Group Kit 3, (Thousand Oaks, Californien: Sage).

Lambert, J. (2006) 'One step closer to a pan-european shopping center standard. Illustrating the new framework with examples', ICSC (International Council of Shopping Centers): Research Review, 13(2), Online: http://www.icsc.org/srch/ lib/euro_standard_only.pdf

Leo, P.-Y. and Philippe, J. (2002) 'Retail centres: Location and consumer's satisfaction', The Service Industries Journal, 22(1), pp. 122-146.

Levy, M. and Weitz, B. A. (2006) Retailing management, (Boston: McGraw-Hill).

Moreno-Jiménez, A. (2001) 'Interurban shopping, new town planning and local development in Madrid metropolitan area ', Journal of Retailing and Consumer Services, 8(5), pp. 291-298.

Myers, J. H., Alpert, M. I., (1968) 'Determinant buying attitudes: meaning and measurement', Journal of Marketing, 32(4/I), pp. 13-20.

Nelson, R. L. (1958) The selection of retail locations, (New York: F.W. Dodge Corporation).

Nevin, J. R., Houston, M. J. (1980) 'Image as a Component of Attraction to Intraurban Shopping Areas', Journal of Retailing, 56(1), pp. 77-93.

Oppewal, H. and Holyoake, B. (2004) 'Bundling and retail agglomeration effects on shopping 
behavior', Journal of Retailing and Consumer Services, 11(2), pp. 61-74.

Reimers, V. and Clulow, V. (2004) 'Retail concentration: a comparison of spatial convenience in shopping strips and shopping centres', Journal of Retailing and Consumer Services, 11(4), pp. 207-221.

Reinartz, W. J. and Kumar, V. (1999) 'Store-, market-, and consumer-characteristics: The drivers of store performance', Marketing Letters, 10(1), pp. 5-23.

Richards, L. (2002) Using N6 in qualitative research, (London: Sage Publications).

Ruiz, J. P., Chebat, J.-C. and Hansen, P. (2003) 'Another trip to the mall: a segmentation study of customers based on their activities', Journal of Retailing and Consumer Services, 11(1), pp. 1-18.

Severin, V., Louviere, J. J. and Finn, A. (2001) 'The stability of retail shopping choices over time and across countries', Journal of Retailing, 77 (2), pp. 185-202.

Statistik Austria (2007) Statistisches Jahrbuch Österreichs 2006 [statistical yearbook of Austria 2006), (Vienna: Verlag Österreich).

Teller, C. and Reutterer, T. (2008) 'The evolving concept of retail attractiveness: What makes retail agglomerations attractive when customer shop at them?' Journal of Retailing and Consumer Services, 15 (3), pp. 127-143.

Thomas, C., Bromley, R. D. F. and Tallon, A. (2006) 'New 'HIGH Streets in the Suburbs? The growing competitive impact of evolving retail parks', International Review of Retail, Distribution \& Consumer Research, 16(1), pp. 43-68.

Van der Waerden, P., Borgers, A. and Timmermans, H. (1998) 'The impact of the parking situation in shopping centres on store choice behaviour', GeoJournal, 45(4), pp. 309315

Van Kenhove, P., De Wulf, K. and Van Waterschoot, W. (1999) 'The impact of task Definition on store-attribute saliences and store choice', Journal of Retailing, 75(1), pp. 125-137.

Wakefield, K. L. and Baker, J. (1998) 'Excitement at the mall: Determinants and effects on shopping response', Journal of Retailing, 74(4), pp. 515-539.

Warnaby, G. and Medway, D. (2004) 'The role of place Marketing as a competititve response 
by town centres to out-of-town retail developments', International Review of Retail, Distribution and Consumer Research, 14(4), pp. 457-477.

Warnaby, G., Bennison, D., Davies, B. J. and Hughes, H. (2002) 'Marketing UK towns and cities as shopping destinations', Journal of Marketing Management, 18(9/10), pp. 877904.

Warnaby, G., Bennison, D., Davies, B. J. and Hughes, H. (2003) 'How important is retail in the marketing of towns and cities? Public sector perspectives', European Retail Digest, 38, pp. 1-4.

Warnaby, G., Bennison, D., Davies, B. J. and Hughes, H. (2004) 'People and partnerships: marketing urban retailing', International Journal of Retail \& Distribution Management, 32 (11), pp. 545-556.

WES (Wiener Einkaufsstrassen) (2007): Wiener Einkaufsstraßen online. Online: http://www.wienereinkaufsstrassen.at/.

Whysall, P. (1995) 'Regenerating inner city shopping centres. The British experience ', Journal of Retailing and Consumer Services, 2(1), pp. 3-13.

Woodside, A. G. and Trappey, R. J. (1992) 'Finding out why customers shop your store and buy your brand: Automatic cognitive processing models of primary choice', Journal of Advertising Research, 32 (6), pp. 59-78.

Wrigley, N. and Lowe, M. (2002) Reading retail. A geographical perspective on retailing and consumption spaces, (London: Arnold).

\section{ACKNOWLEDGEMENTS}

This research was supported by the 'Festo Fellow Fond' awarded to the author, who would like to thank the 'Festo GmbH' for its support. The author also wishes to thank Prof David B. Grant at University of Hull for useful comments on drafts of this paper and the three anonymous reviewers and the editors for their helpful suggestions. 
Appendix 1: Rating results and local fit measures

\begin{tabular}{|c|c|c|c|c|c|c|c|c|c|c|}
\hline \multicolumn{11}{|c|}{ EXOGENOUS MEASUREMENT MODELS } \\
\hline \multirow{2}{*}{$\begin{array}{r}\text { Agglomeration format } \\
\text { Measures/Indices }\end{array}$} & \multicolumn{2}{|c|}{ sMAL } & \multicolumn{2}{|c|}{ rMAL } & \multirow[b]{2}{*}{ Diff. } & \multicolumn{2}{|c|}{ sSST } & \multicolumn{2}{|c|}{ rSST } & \multirow[b]{2}{*}{ Diff. } \\
\hline & $\mu(\sigma)$ & $\begin{array}{c}\rho / \alpha \\
\text { AVE/FLR }\end{array}$ & $\mu(\sigma)$ & $\begin{array}{c}\rho / \alpha \\
\text { AVE/FLR }\end{array}$ & & $\mu(\sigma)$ & $\begin{array}{c}\rho / \alpha \\
\text { AVE/FLR }\end{array}$ & $\mu(\sigma)$ & $\begin{array}{c}\rho / \alpha \\
\text { AVE/FLR }\end{array}$ & \\
\hline $\begin{array}{l}\text { Accessibility }\left(\xi_{1}\right) \\
\text { You can easily get to .... a } \\
\text { You can get to ... quickly. }{ }^{\text {a }} \\
\text { You can get to ... without problems. }{ }^{\text {a }}\end{array}$ & $\begin{array}{l}4.7(1.5) \\
4.5(1.5) \\
4.6(1.5)\end{array}$ & $\begin{array}{l}.9 / .9 \\
.76 / .1\end{array}$ & $\begin{array}{l}5.1(1.3) \\
4.9(1.4) \\
5.1(1.3) \\
\end{array}$ & $\begin{array}{l}.94 / .94 \\
.84 / .1\end{array}$ & $\begin{array}{l}* * * \\
\star * * \\
\star * *\end{array}$ & $\begin{array}{l}4.5(1.5) \\
4.3(1.7) \\
4.6(1.5) \\
\end{array}$ & $\begin{array}{l}.94 / .94 \\
.84 / .12\end{array}$ & $\begin{array}{l}5.2(1.2) \\
5.1(1.3) \\
5.2(1.2)\end{array}$ & $\begin{array}{l}.96 / .96 \\
.88 / .11\end{array}$ & $\begin{array}{l}* * * \\
* * * \\
* * *\end{array}$ \\
\hline $\begin{array}{l}\text { Parking }\left(\xi_{2}\right) \\
\ldots \text { has always enough free parking lots }{ }^{\text {a }} \\
\text { Parking fees are in an acceptable range in .... }{ }^{a} \\
\ldots \text { offers different parking facilities sufficiently. }\end{array}$ & $\begin{array}{c}3.7(1.8) \\
5(1.5) \\
4(1.6) \\
\end{array}$ & $\begin{array}{l}.75 / .68 \\
.53 / .2\end{array}$ & $\begin{array}{l}3.7(1.9) \\
4.2(1.8) \\
3.4(1.9)\end{array}$ & $\begin{array}{l}.87 / .87 \\
.69 / .48\end{array}$ & $\begin{array}{l}- \\
* * * \\
* * *\end{array}$ & $\begin{array}{l}.7(1.1) \\
1.4(1.4) \\
1.2(1.3)\end{array}$ & $\begin{array}{l}.79 / .79 \\
.56 / .26\end{array}$ & $\begin{array}{l}1.6(1.5) \\
2.4(1.6) \\
1.8(1.6)\end{array}$ & $\begin{array}{l}.85 / .85 \\
.67 / .35\end{array}$ & $\begin{array}{l}* * * \\
* * * \\
* * *\end{array}$ \\
\hline $\begin{array}{l}\text { Retail tenant } \operatorname{mix}\left(\xi_{3}\right) \\
\ldots \text { has a broad range of retail stores. }{ }^{a} \\
\ldots \text { has an attractive range of retail stores. } \\
\text { Many well-known retail stores are in .... }\end{array}$ & $\begin{array}{c}5(1.2) \\
4.8(1.2) \\
5.1(1)\end{array}$ & $\begin{array}{l}.91 / .91 \\
.78 / .35\end{array}$ & $\begin{array}{c}3.9(1.4) \\
4(1.4) \\
4.3(1.3)\end{array}$ & $\begin{array}{l}.87 / .87 \\
.69 / .29\end{array}$ & $\begin{array}{l}* * * \\
\star * * \\
* * *\end{array}$ & $\begin{array}{l}5.1(1.1) \\
5.1(1.1) \\
5.3(.9)\end{array}$ & $\begin{array}{l}.91 / .9 \\
.76 / .26\end{array}$ & $\begin{array}{l}3.9(1.5) \\
3.6(1.7) \\
3.9(1.5)\end{array}$ & $\begin{array}{l}.91 / .91 \\
.77 / .74\end{array}$ & $\begin{array}{l}* * * \\
* * * \\
* * *\end{array}$ \\
\hline $\begin{array}{l}\text { Non-retail tenant } \operatorname{mix}\left(\xi_{4}\right) \\
\ldots \text { has a broad range of bars and restaurants. }{ }^{a} \\
\ldots \text { offers a broad range of entertainment facilities. }{ }^{a}\end{array}$ & $\begin{array}{c}4.6(1.3) \\
4(1.5)\end{array}$ & $\begin{array}{l}.74 / .74 \\
.59 / .46 \\
\end{array}$ & $\begin{array}{c}3.6(1.7) \\
2.9(2)\end{array}$ & $\begin{array}{l}.84 / .83 \\
.72 / .45 \\
\end{array}$ & $\begin{array}{l}* * * \\
* * * \\
\end{array}$ & $\begin{array}{l}4.6(1.4) \\
3.6(1.6)\end{array}$ & $\begin{array}{l}.68 / .7 \\
.51 / .39\end{array}$ & $\begin{array}{l}3.5(1.7) \\
2.3(1.7) \\
\end{array}$ & $\begin{array}{l}.72 / .72 \\
.57 / .96 \\
\end{array}$ & $* * *$ \\
\hline $\begin{array}{l}\text { Merchandise value }\left(\xi_{5}\right) \\
\text { The overall price level is low in .... } \\
\text { You can find a lot of special offers in .... a } \\
\text { The price-quality ratio is good in .... }\end{array}$ & $\begin{array}{c}2.6(1.1) \\
3.3(1.1) \\
3.5(1) \\
\end{array}$ & $\begin{array}{l}.81 / .81 \\
.59 / .36\end{array}$ & $\begin{array}{c}2.6(1.3) \\
3(1.3) \\
3.3(1.1) \\
\end{array}$ & $\begin{array}{l}.82 / .81 \\
.61 / .29\end{array}$ & $\begin{array}{c}- \\
* * * \\
* * \\
\end{array}$ & $\begin{array}{l}2.5(1.4) \\
3.2(1.4) \\
3.3(1.2)\end{array}$ & $\begin{array}{l}.84 / .83 \\
.64 / .23\end{array}$ & $\begin{array}{l}3(1.3) \\
3.4(1.2) \\
3.6(1.1)\end{array}$ & $\begin{array}{l}.87 / .87 \\
.7 / .25\end{array}$ & $\begin{array}{l}* * * \\
- \\
-\end{array}$ \\
\hline $\begin{array}{l}\text { Personnel }\left(\xi_{6}\right) \\
\text { Personnel are friendly in .... }{ }^{a} \\
\text { Personnel are competent in .... } \\
\text { Personnel are helpful in ..... }\end{array}$ & $\begin{array}{l}3.7(1.3) \\
3.5(1.3) \\
3.7(1.3)\end{array}$ & $\begin{array}{l}.93 / .93 \\
.81 / .34\end{array}$ & $\begin{array}{l}3.9(1.2) \\
3.6(1.3) \\
3.7(1.3)\end{array}$ & $\begin{array}{l}.93 / .93 \\
.82 / .41\end{array}$ & $\begin{array}{l}- \\
- \\
-\end{array}$ & $\begin{array}{l}3.8(1.3) \\
3.7(1.3) \\
3.7(1.3)\end{array}$ & $\begin{array}{l}.95 / .95 \\
.87 / .27\end{array}$ & $\begin{array}{l}3.8(1.3) \\
3.6(1.4) \\
3.7(1.4)\end{array}$ & $\begin{array}{l}.95 / .95 \\
.87 / .34\end{array}$ & $\begin{array}{l}- \\
- \\
-\end{array}$ \\
\hline $\begin{array}{l}\text { Atmosphere }\left(\xi_{7}\right) \\
\text { Sensory stimuli* are pleasant in .... } \\
\text { There is a good mood in .... } \\
\text { The atmosphere is pleasant in .... }\end{array}$ & $\begin{array}{l}3.3(.7) \\
3.1(1.4) \\
3.1(1.4)\end{array}$ & $\begin{array}{l}.93 / .83 \\
.85 / .33\end{array}$ & $\begin{array}{l}3.3(.7) \\
3.5(1.4) \\
3.5(1.4)\end{array}$ & $\begin{array}{l}.93 / .84 \\
.83 / .26\end{array}$ & $\begin{array}{c}* \\
* * \\
* *\end{array}$ & $\begin{array}{c}3.3(.7) \\
3.5(1.5) \\
3.6(1.5)\end{array}$ & $\begin{array}{l}.93 / .82 \\
.8 / .37\end{array}$ & $\begin{array}{c}3.1(.8) \\
3.1(1.4) \\
3.1(1.5)\end{array}$ & $\begin{array}{c}.91 / .83 \\
.8 / .37\end{array}$ & $\begin{array}{l}* * * \\
* * * \\
* * *\end{array}$ \\
\hline $\begin{array}{l}\text { Orientation }\left(\xi_{8}\right) \\
\text { You can move around safely and quickly in .... } \\
\text { You can easily orientate themselves within } \ldots . .{ }^{a} \\
\text { Stores are arranged clearly in the AGG. }{ }^{a}\end{array}$ & $\begin{array}{c}3.8(1.5) \\
4(1.7) \\
3.7(1.6)\end{array}$ & $\begin{array}{l}.8 / .76 \\
.59 / .32\end{array}$ & $\begin{array}{l}4.4(1.4) \\
4.6(1.3) \\
4.2(1.5)\end{array}$ & $\begin{array}{l}.88 / .8 \\
.72 / .48\end{array}$ & $\begin{array}{l}* * * \\
* * * \\
\star * *\end{array}$ & $\begin{array}{l}3.2(1.7) \\
4.3(1.4) \\
3.8(1.5)\end{array}$ & $\begin{array}{l}.76 / .74 \\
.52 / .82\end{array}$ & $\begin{array}{l}4.1(1.4) \\
4.6(1.2) \\
4.1(1.3)\end{array}$ & $\begin{array}{l}.88 / .77 \\
.71 / .26\end{array}$ & $\begin{array}{l}* * * \\
- \\
-\end{array}$ \\
\hline $\begin{array}{l}\text { Infrastructural services }\left(\xi_{9}\right) \\
\text { There are enough toilets in .... } \\
\ldots \text { has enough cash dispensers. } \\
\ldots \text { offers enough recreational areas. } \\
\ldots\end{array}$ & $\begin{array}{c}3(1.8) \\
3.1(1.6) \\
2.1(1.5) \\
\end{array}$ & $\begin{array}{l}.75 / .74 \\
.5 / .57\end{array}$ & $\begin{array}{l}3.1(1.7) \\
2.8(1.7) \\
2.3(1.6) \\
\end{array}$ & $\begin{array}{l}.77 / .76 \\
.52 / .45\end{array}$ & $\begin{array}{l}- \\
* \\
-\end{array}$ & $\begin{array}{c}1.6(1.4) \\
4(1.4) \\
2.3(1.6) \\
\end{array}$ & $\begin{array}{l}.62 / .63 \\
.36 / .82\end{array}$ & $\begin{array}{l}1.5(1.4) \\
3.9(1.5) \\
2.8(1.7) \\
\end{array}$ & $\begin{array}{l}.62 / .61 \\
.4 / .82\end{array}$ & $\begin{array}{c}- \\
- \\
* * * \\
\end{array}$ \\
\hline
\end{tabular}




\begin{tabular}{|c|c|c|c|c|c|c|c|c|c|c|}
\hline \multicolumn{11}{|c|}{ ENDOGENOUS MEASUREMENT MODELS } \\
\hline \multirow{2}{*}{$\begin{array}{r}\text { Agglomeration format } \\
\text { Measures/Indices }\end{array}$} & \multicolumn{2}{|c|}{ SMAL } & \multicolumn{2}{|c|}{ rMAL } & \multirow[b]{2}{*}{ Diff. } & \multicolumn{2}{|c|}{ sSST } & \multicolumn{2}{|c|}{ rSST } & \multirow[b]{2}{*}{ Diff. } \\
\hline & $\mu(\sigma)$ & $\begin{array}{c}\rho / \alpha \\
\text { AVE/FLR }\end{array}$ & $\mu(\sigma)$ & $\begin{array}{c}\rho / \alpha \\
\text { AVE/FLR }\end{array}$ & & $\mu(\sigma)$ & $\begin{array}{c}\rho / \alpha \\
\text { AVE/FLR }\end{array}$ & $\mu(\sigma)$ & $\begin{array}{c}\rho / \alpha \\
\text { AVE/FLR }\end{array}$ & \\
\hline Satisfaction $\left(n_{1}\right)$ & & & & \multirow{4}{*}{$\begin{array}{l}.86 / .86 \\
.68 / .81\end{array}$} & & & \multirow{4}{*}{$\begin{array}{l}.82 / .87 \\
.61 / .75\end{array}$} & & \multirow{4}{*}{$\begin{array}{l}.91 / .9 \\
.76 / .85\end{array}$} & \\
\hline How satisfied are you with ... (very dis-/-satisfied $)^{c}$ & $5.7(1.1)$ & \multirow{3}{*}{$\begin{array}{l}.85 / .84 \\
.65 / .8\end{array}$} & $5.2(1.2)$ & & $* * *$ & $5.6(1.2)$ & & $4.7(1.5)$ & & *** \\
\hline How does ... meet your expectations (not at all/totally) ${ }^{c}$ & $5.6(1)$ & & $5.1(1.2)$ & & $* * *$ & $5.6(1.1)$ & & $4.7(1.5)$ & & *** \\
\hline $\begin{array}{l}\text { Think of an ideal EAF/CAF. To what extent does } \ldots \\
\text { comes close to that? (not close/very close) }\end{array}$ & $5.2(1.3)$ & & $4.5(1.4)$ & & $* * *$ & $5.2(1.3)$ & & $4.2(1.6)$ & & $* * *$ \\
\hline \multicolumn{11}{|l|}{ Patronage intention $\left(\eta_{3}\right)$} \\
\hline $\begin{array}{l}\text { Would you recommend the } \ldots \text { ot other persons } \\
\text { (definitely not/definitely yes) }\end{array}$ & $7(1.7)$ & \multirow{2}{*}{$\begin{array}{l}.8 / .75 \\
.68 / .76\end{array}$} & $6.2(1.9)$ & \multirow{2}{*}{$\begin{array}{l}.83 / .76 \\
.72 / .77\end{array}$} & $* * *$ & $7.2(1.7)$ & \multirow{2}{*}{$\begin{array}{l}.87 / .82 \\
.78 / .58\end{array}$} & $5.3(2.5)$ & \multirow{2}{*}{$\begin{array}{l}.83 / .76 \\
.73 / .9\end{array}$} & $* * *$ \\
\hline $\begin{array}{l}\text { How likely are you to go to .... again and buy } \\
\text { somenthing (very unlikely/very likely) }\end{array}$ & $7.9(1.5)$ & & $7.4(1.6)$ & & $* * *$ & $7.9(1.5)$ & & $7(2.1)$ & & $* * *$ \\
\hline
\end{tabular}

\section{Notions:}

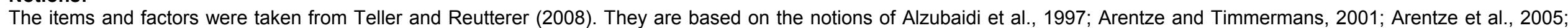

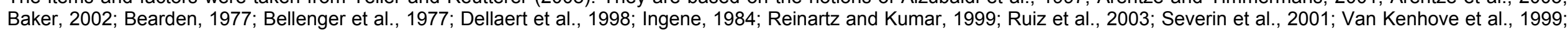

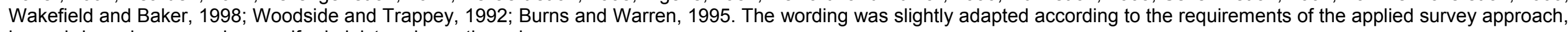
i.e. web-based survey using a self-administered questionnaire.

Cutoff values for measurement validity: $\alpha>.7$; $p>.6$; AVE>.5; FLR<1 (Fornell and Larcker, 1981; Baggozzi and Yi, 1988)

Sample sizes: $n_{\mathrm{SMAL}}=380 ; \mathrm{n}_{\mathrm{rMAL}}=451 ; \mathrm{n}_{\mathrm{SSST}}=602 ; \mathrm{n}_{\mathrm{rSST}}=227$;

\section{Caption:}

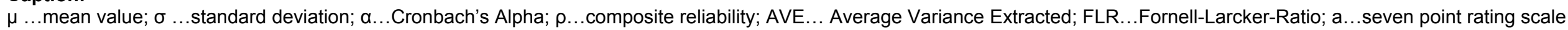
(anchors $0-6$; totally disagree - totally agree); b...metric scale; c...seven point rating scale (anchors -3 to +3 ; recoded to $1-7$ ); $d . .$. ten point rating scale (anchors 0 and $9 ;{ }^{*} . .$. sensory stimuli denote for aroma and air, temperature, lightness, cleanliness and architecture, the ratings of each stimuli item were comprised by calculating mean values. Diff.... significant difference between ratings of SMAL and rMAL/sSST and rSST (Mann-Whitney-U-Test); - ...not significant $(p>.05) ;{ }^{*} \ldots p<.05 ;{ }^{* *} \ldots . .0<.01 ;{ }^{* * *} \ldots . p<.001$; 